\title{
A relação entre homem e ambiente expressa no léxico: um estudo das metáforas que nomeiam a "menstruação"
}

DOI: http://dx.doi.org/10.21165/el.v49i3.2718

Vanessa Cristina Martins Benke'

\section{Resumo}

Este trabalho realiza um estudo léxico-semântico das designações metafóricas que nomeiam a "menstruação" na fala dos habitantes das capitais do Brasil, com o objetivo de analisar a relação entre léxico e ambiente, como também discutir os possíveis traços semânticos atribuídos pelos falantes no processo de nomeação do período fisiológico em questão. Foram analisadas nove metáforas designativas para o conceito "as mulheres perdem sangue todos os meses. Como se chama isso?", questão 121 do Questionário Semântico Lexical (QSL), área semântica ciclos da vida do Projeto Atlas Linguístico do Brasil - Projeto ALiB. O estudo confirmou a estreita relação entre léxico e ambiente físico, bem como apontou aspectos de natureza sociocultural, histórico e geográfico revelados no léxico examinado.

Palavras-chave: léxico; menstruação; metáforas; capitais do Brasil.

1 Universidade Federal de Mato Grosso do Sul (UFMS), Campo Grande, Mato Grosso do Sul, Brasil; vcmbenke@hotmail.com; https://orcid.org/0000-0001-8539-9070 


\section{La relación entre hombre y ambiente expresado en el léxico: un estudio de las metáforas que nombran la "menstruación"}

\section{Resumen}

Este trabajo realiza un estudio léxico-semántico sobre designaciones metafóricas que nombran la "menstruación" en el discurso de los habitantes de las capitales de Brasil, con el objetivo de analizar la relación entre léxico y ambiente, así como discutir las posibles características semánticas atribuidas por los hablantes en el proceso de denominación del período fisiológico en cuestión. Se analizaron nueve metáforas designativas para el concepto "las mujeres pierden sangre todos los meses. Cómo se denomina eso?", cuestión 121 de del Cuestionario Semántico Léxico (QSL), área semántica ciclos de vida del Proyecto Atlas Lingüístico de Brasil - Proyecto ALiB. El estudio confirmó la estrecha relación entre el léxico y el entorno físico, y señaló aspectos de la naturaleza sociocultural, histórica y geográfica revelados en el léxico examinado.

Palabras clave: léxico; menstruación; metáforas; capitales de Brasil.

\section{Introdução}

Determinados assuntos, no âmbito social, incitam, entre os indivíduos de um grupo sociolinguístico, o sentimento de pudor/decoro, revelando, neste caso, aspectos da visão de mundo de uma comunidade. Assim, é corriqueiro, por exemplo, temas relacionados ao sexo ou a certas partes e funções do corpo humano serem motivo de tabus e, em razão disso, tendem a ser evitados. Nesse sentido, no âmbito da fisiologia humana feminina, nomeadamente, "a menstruação", é bastante comum a manifestação de vergonha e constrangimento, sobretudo, no tocante às nomeações designadas a esse referente, o que o torna um campo fértil de interdição linguística, dado o seu caráter tabuístico. Por essa razão, o falante vale-se de diferentes meios de substituição no intuito de amenizar o conteúdo semântico "negativo" expresso pelo vocábulo tido como tabu, optando, assim, por formas linguísticas eufêmicas como é o caso do recurso metafórico: "os tabus linguísticos facilitam a difusão de criações metafóricas, pois as palavras tidas como tabus, ao serem evitadas, são substituídas por empréstimos, eufemismos, circunlóquios, metáforas, antífrases, etc." (COSERIU, 1982, p. 69).

Assim, partindo do pressuposto de que o uso do recurso metafórico, no processo de nomeação, não se configura como um fenômeno meramente linguístico, mas também cognitivo, que, por sua vez, revela traços de natureza sociocultural, histórico e geográfico no léxico de um grupo de falantes, este trabalho tem como objetivo examinar a relação entre homem e ambiente expressa nas nomeações metafóricas para a pergunta: "as mulheres perdem sangue todos os meses. Como se chama isso?" (COMITÊ NACIONAL DO PROJETO ALIB, 2001, p. 31), que integra o Questionário Semântico-Lexical (QSL/121), 
vinculada à área semântica ciclos da vida do Projeto $\mathrm{ALiB}^{2}$, por meio de entrevistas realizadas com 200 informantes de 25 capitais $^{3}$ do Brasil. Este trabalho busca discutir as relações associativas entre léxico e ambiente evidenciadas no vocabulário do grupo examinado, especialmente, nas metáforas designativas documentadas para a "menstruação", na perspectiva teórica de Sapir (1969)4.

Tendo em vista a natureza do corpus selecionado para este estudo, isto é, dados geolinguísticos extraídos da base de dados do Projeto Atlas Linguístico do Brasil (Projeto ALiB), buscou-se respaldo teórico-metodológico na Lexicologia, na Semântica, na Dialetologia e na Geolinguística, além de fundamentos em áreas afins como a Antropologia, e a Etnolinguística, considerando, nesse particular, o intuito de examinar a inter-relação entre língua, sociedade e cultura a partir dos fatos linguísticos registrados nas capitais do Brasil.

\section{Pressupostos teóricos}

O sangue que as mulheres perdem todos os meses ultrapassa o campo dos fenômenos fisiológicos. Há de assinalar que, em se tratando de um ciclo biológico inerente à mulher, é incoerente, pois, desassociá-lo de seus aspectos sociais e culturais. Isso explica, portanto, o porquê de esse assunto ser considerado um tabu na sociedade. Nessa perspectiva, Câmara Cascudo (1972), por exemplo, registra, no verbete "menstruada", inúmeros exemplos que confirmam a configuração tabuística da menstruação:

[...] a mulher com o fluxo catamenial, boi, regras, paquete, é tabu universal. Não pode atravessar água corrente, deitar galinhas para o choco, tocar em crianças doentes, em líquidos que estão em fermentação, nas árvores com frutos verdes, fazer a cama dos recém-casados, dar o primeiro banho numa criança ou o primeiro leite, mesmo por mamadeira, amamentar, assistir a batizado, sepultamento de adultos (tabu para a menstruada), guardar frutos para amadurecer, enfim é uma força negativa, um obstáculo vivo, um poder maléfico inconsciente para

20 Projeto ALiB adota critérios metodológicos quanto ao perfil dos entrevistados, estes devem ser: nascidos e criados na localidade pesquisada e com pais também oriundos da mesma localidade, compreendendo as duas faixas etárias: faixa I - jovens (18 a 30); faixa II - idosos (50 a 65), de ambos os sexos. Quanto à escolaridade, o informante deve ter cursado o Ensino Fundamental incompleto (localidades do interior dos Estados e nas capitais) e Ensino Superior (capitais). Maiores informações acerca do Projeto ALiB estão disponíveis no endereço www.alib.ufba.br.

3 Palmas, capital do Estado de Tocantins, e Brasília (Distrito Federal) não integram a rede de pontos de pesquisa do Projeto ALiB, pois são cidades fundadas recentemente, respectivamente, em 1990 e 1960, não possuindo, portanto, uma norma linguística consolidada.

4 Para este artigo, foram discutidos parte dos resultados que compõem o corpus da pesquisa de Mestrado que teve como objeto de estudo o léxico na perspectiva dos tabus linguísticos. 
tudo quanto represente ou constitua início de desenvolvimento, desdobração, crescimento [...] (CÂMARA CASCUDO, 1972, p. 574).

Nessa mesma percepção mitológica do sangue e da sua representação sociocultural no contexto do período menstrual, Chevalier e Gheerbrant (2008, p. 944-945) registram que o "vermelho-escuro" possui uma significação fúnebre para a cultura pagã, no que diz respeito à "menstruação":

[...] o interdito que atinge as mulheres menstruadas: o sangue que deitam fora é impuro, porque, ao passar da noite uterina ao dia, ele inverte sua polaridade e passa do direito ao esquerdo. Essas mulheres são intocáveis e em numerosas sociedades elas são obrigadas a realizar um retiro purificador antes de se reintegrar à sociedade da qual foram, temporariamente, excluídas.

No contexto bíblico, também há referência à mulher menstruada, especialmente, no que diz respeito às regras que se devem cumprir durante o período em questão5:

[...] mas a mulher, quando tiver fluxo, e o seu fluxo de sangue estiver na sua carne, estará sete dias na sua separação, e qualquer que a tocar, será imundo até à tarde. E tudo aquilo sobre o que ela se deitar durante a sua separação, será imundo; e tudo sobre o que se assentar, será imundo. E qualquer que tocar na sua cama lavará as suas vestes, e se banhará com água, e será imundo até à tarde. E qualquer que tocar alguma coisa, sobre o que ela se tiver assentado, lavará as suas vestes, e se banhará com água, e será imundo até à tarde. (BÍBLIA ONLINE, 2011).

Nota-se, portanto, que a menstruação é permeada de crenças, condutas e atitudes que abarcam diferentes âmbitos sociais, quer seja o religioso, o mitológico ou o folclórico. Tais crenças, como se pôde notar nas assertivas aludidas, implicam determinadas regras às mulheres que estejam nesse período, como se retirarem e se guardarem, e não executarem certas tarefas. Nesse contexto, é corriqueiro, mesmo numa sociedade pós-moderna, atitudes que reportam a essas crenças, como frases assim: "não lave o cabelo se estiver menstruada!" ou "não faça bolo ou pão, pois não irão fermentar". Esses costumes e tantos outros, que envolvem a menstruação, acabam sendo interiorizados pelos indivíduos de uma sociedade, moldando-os, portanto, a uma dada maneira de ver e conceber o mundo.

5 Bíblia on-line (Livro de Levítico, capítulo 15, versículos 19-22). Disponível em: http://www. bibliaonline.com.br/acf/gn/1. Acesso em: 20 jun. 2011. 
De acordo com o exposto, pode-se compreender a "menstruação" não somente sob o ponto de vista biológico, ou seja, o de expelir sangue todos os meses, mas também sob a ótica da antropologia, haja vista toda a inferência sociocultural e ideológica em torno dessa fisiologia das mulheres. Esses aspectos, por sua vez, tendem a se refletir na língua, sobretudo, no léxico, já que esse é o nível da língua que "mais nitidamente reflete o ambiente físico e social dos falantes" (SAPIR, 1969, p. 45).

Nessa perspectiva, Sapir (1954, p. 205) defende que a língua existe a partir de sua interrelação com a sociedade e a cultura, definindo-a como "um conjunto socialmente herdado de práticas e crenças que determinam a trama das nossas vidas". Em investigações sobre o léxico, outra vertente pode ser estabelecida: a sua relação com o ambiente. Ao discutir essa relação, Sapir (1969, p. 43-44) pondera que "há uma forte tendência a atribuir muitos elementos da cultura humana à influência do ambiente em que se acham situados os participantes dessa cultura [...]".

Essa proposição nos reporta à tese do "relativismo linguístico", postulado inicialmente por Sapir (1969, p. 20), e depois por Whorf, numa versão considerada radical, que defendia a tese de que a língua é um guia para a "realidade social", sendo assim impossível um indivíduo se ajustar à realidade sem o seu auxílio. Ao discutir a hipótese Sapir-Whorf, Biderman (2001, p. 109) esclarece que essa teoria sustenta a ideia de que "cada língua traduz o mundo e a realidade social segundo o seu próprio modelo, refletindo uma cosmovisão que lhe é própria, expressa nas suas categorias gramaticais e léxicas".Com base nesses pressupostos, pode-se conceber a língua e, sobretudo, o léxico como um sistema veiculador da realidade sociocultural de determinada comunidade linguística.

Nesse particular, situam-se os tabus linguísticos, caracterizados por certas palavras ou expressões que, segundo crenças ou imposições sociais, não devem ser pronunciadas. Assim, condicionada a esses aspectos, a proferição de determinadas palavras é evitada com o fim de não causar desconforto ou ofender a outrem. Ademais, existem as palavras tabus oriundas do âmbito mágico-religioso que, segundo crenças, são dotadas de poder sobrenatural e se proferidas podem evocar alguma desgraça ao falante. Nesse caso, a palavra tabu não é proferida e quase sempre é substituída por outra desprovida de "poder sobrenatural". Sobre os vocábulos tabus, Guérios (1979, p. 1) pondera que "as palavras exteriorizadas podem ter forças sobrenaturais benéficas ou maléficas, porém há palavras que não devem ser exteriorizadas, a fim de se evitarem malefícios dos mesmos poderes".

Em decorrência dessas proibições vocabulares, o usuário da língua lança mão de diferentes recursos de substituição ${ }^{6}$ no intuito de amenizar a carga semântica contida na

6 Guérios (1979) elenca vários processos substitutivos do vocábulo tabu, a saber: gesticulação, uso de sinônimos, expressões genéricas, estrangeirismo ou dialetismo, hipocorístico, disfemismo, diminutivo, deformações fonéticas, entre outros. 
palavra interdita, dentre eles, o eufemismo: "na maioria dos casos, embora não em todos, a palavra tabu será abandonada e introduzir-se-á um substituto inofensivo, um eufemismo do grego eu "bem" + pheme "falar" (ULLMANN, 1964, p. 426). Logo, o eufemismo é "toda maneira atenuada ou suavizada de exprimir certos fatos ou ideias cuja crueza pode ferir" (DUBOIS et al., 2006, p. 255).

Cabe destacar que o recurso metafórico se enquadra no campo dos eufemismos. Portanto, do ponto de vista linguístico, a metáfora consiste na substituição da denotação por um conteúdo de representação, podendo-se valer de um conteúdo análogo, conforme definido por Cassirer (1972, p. 104-105):

[...] ocorreria na metáfora uma genuína 'transposição'; os dois conteúdos, entre os quais ela vai e vem, apresentam-se com significados por si determinados e independentes, e entre ambos, considerados como pontos estáveis de partida e chegada, como terminus a quo et terminus ad quem já dados, há lugar agora para o movimento da representação, que leva a transladar de um para outro e a substituir, conforme a expressão, um pelo outro.

Contudo, Cassirer (1972, p. 103-104) assevera que a metáfora pode ser vista não apenas como um recurso meramente linguístico, em que se permite a transposição do sentido de uma determinada palavra a outra, mas também, sob a perspectiva do subjetivismo, ou seja, como um meio de o indivíduo expressar seus sentimentos:

[...] o homem, quisesse ou não, foi forçado a falar metaforicamente, e isto não porque não Ihe fosse possível frear sua fantasia poética, mas antes porque devia esforçar-se ao máximo para dar expressão adequada às necessidades sempre crescentes de seu espírito. Portanto, por metáfora não mais se deve entender simplesmente a atividade deliberada de um poeta, a transposição consciente de uma palavra que passa de um objeto a outro. Esta é a moderna metáfora individual, que é um fruto da fantasia, enquanto que a metáfora antiga era mais frequente uma questão de necessidade e, na maior parte dos casos, foi mais a transposição de uma palavra levada de um conceito a outro do que a criação ou determinação mais rigorosa de um novo conceito, por meio de um velho nome.

As metáforas são utilizadas, portanto, pelo usuário da língua no processo de nomeação de conceitos básicos das suas experiências e interações com o mundo em que vive, revelando marcas de natureza sociocultural pertencentes a um grupo sociocultural e contribuindo para a atribuição de novos valores semânticos e para a renovação da linguagem. Nessa perspectiva: "[...] a metáfora está infiltrada na vida cotidiana, não somente na linguagem, mas também no pensamento e na ação. Nosso sistema conceptual ordinário, em termos do qual não só pensamos, mas também agimos, é fundamentalmente metafórico por natureza" (LAKOFF; JOHNSON, 2002, p. 45). 
Nesse contexto, Zanotto et al. (apud LAKOFF; JOHNSON, 2002, p. 33) defendem que a "metáfora é indiscutivelmente de natureza conceptual, pois é um importante instrumento do nosso aparato cognitivo". Isso demonstra que a metáfora não se caracteriza apenas como um recurso estilístico, mas também está associada ao aspecto cognitivo do indivíduo e da sua interação com o mundo em que vive, refletindo, assim, a cosmovisão de uma civilização.

Vale ressaltar que o estudo da área semântica ciclos da vida, especificamente, da "menstruação", selecionada para este artigo, foi relevante na medida em que permitiu resgatar os valores culturais e sociais pertencentes ao grupo investigado, além de crenças e atitudes linguísticas do falante frente ao assunto em questão, manifestados por sentimentos de pudor/decoro, evidenciados na seleção lexical no ato de nomear o conceito pesquisado. Em síntese, este estudo referendou a estreita relação entre as escolhas lexicais dos falantes e a cosmovisão de uma sociedade.

Dando continuidade a este texto, na sequência, temos a apresentação e análise dos dados, examinados sob as perspectivas diatópica e léxico-semântica, objetivando compreender aspectos relativos à maneira como um povo vê e concebe a realidade em que vive, materializados, por sua vez, no léxico da língua, contribuindo, portanto, para um maior conhecimento da realidade sócio-histórico-cultural das capitais do Brasil.

\section{Apresentação e análise dos dados}

Os inquéritos realizados pelo Projeto ALiB, nas capitais do Brasil, documentaram nove designações de caráter metafórico para nomear "o sangue que as mulheres perdem todos os meses" (121/QSL): boi/variantes, bode/variantes, chico/variantes ${ }^{7}$, sinal vermelho, bandeira/bandeira vermelha, paquete, escrever com tinta vermelha, estar moranguinho e

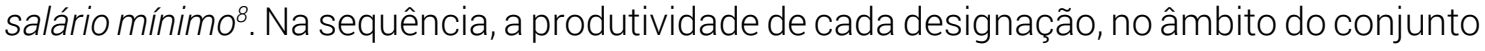
dos dados examinados, pode ser vista na Tabela 1.

70 termo variantes refere-se às designações de natureza fraseológica documentadas para o conceito pesquisado, derivadas, por sua vez, das unidades lexicais "bases": boi, bode e chico (detalhadas no Quadro 1 deste artigo).

8 Essa pergunta registrou o total de 50 designações para nomear o referente em questão, porém, para este estudo, foram consideradas somente as de caráter metafórico. 
Tabela 1. Produtividade das designações metafóricas para "menstruação" nas capitais do Brasil

\begin{tabular}{l|l|c}
\hline \multicolumn{1}{c|}{ Designações metafóricas } & $\begin{array}{c}\text { Percentual nas capitais } \\
\text { do Brasil }\end{array}$ & Capitais \\
\hline boi/variantes & $7,23 \%$ & $\begin{array}{c}\text { Salvador, Aracaju, Maceió, Recife, } \\
\text { João Pessoa, Natal, Vitória, } \\
\text { Florianópolis. }\end{array}$ \\
\hline bode/variantes & $6,92 \%$ & $\begin{array}{c}\text { Rio Branco, Porto Velho, Manaus, } \\
\text { Boa Vista, Macapá, Belém, São Luís, } \\
\text { Teresina, Fortaleza. }\end{array}$ \\
\hline chico/variantes & 4,81 & $\begin{array}{c}\text { Curitiba, São Paulo, Belo Horizonte, } \\
\text { Campo Grande, Goiânia, Manaus, São } \\
\text { Luís, Recife, Maceió, Aracaju }\end{array}$ \\
\hline sinal vermelho & $1,20 \%$ & $\begin{array}{c}\text { Belo Horizonte, Goiânia, Boa Vista, } \\
\text { Fortaleza }\end{array}$ \\
\hline bandeira/bandeira vermelha & $0,90 \%$ & São Paulo, Boa Vista, Fortaleza \\
\hline paquete & $0,90 \%$ & Florianópolis \\
\hline escrever com tinta vermelha & $0,30 \%$ & São Luís \\
\hline estar moranguinho & $0,30 \%$ & Recife \\
\hline salário mínimo & $0,30 \%$ & Fortaleza \\
\hline Total: & $22,86 \%$ & - \\
\hline
\end{tabular}

Fonte: Banco de Dados do ALiB. Elaborado pela autora

Na Tabela 1 observa-se, entre as respostas metafóricas para "menstruação", que boi/ variantes, bode/variantes e chico/variantes se destacam entre as mais produtivas, seguida de sinal vermelho, bandeira/bandeira vermelha e paquete, que apresentaram, por seu turno, menor incidência. Já as formas linguísticas escrever com tinta vermelha, estar moranguinho e salário mínimo registraram ocorrências únicas.

\section{Perspectiva geossociolinguística}

No conjunto das metáforas apuradas para a "menstruação", conforme já destacado, figuraram boi, bode e chico. Boi apresentou maior incidência nas capitais da região Nordeste $(13,74 \%)$, ocorrendo em quase todas as capitais dessa região, com exceção de Fortaleza, Teresina e São Luiz. Todavia, foi documentada também nas regiões Sul e Sudeste, respectivamente, nas capitais Florianópolis (11,43\%) e Vitória (3,84\%).

Já a nomeação bode/variantes foi registrada apenas nas capitais do Norte e Nordeste, com ocorrência em todas as capitais do Norte (16,25\%). O Nordeste, por seu turno, 
alcançou o percentual de apenas 7,63\% distribuídos em três capitais: Fortaleza, Teresina e São Luís. A Figura 1, a seguir, apresenta a distribuição espacial de bode/variantes.

Figura 1. Distribuição diatópica de bode/variantes nas capitais do Brasil

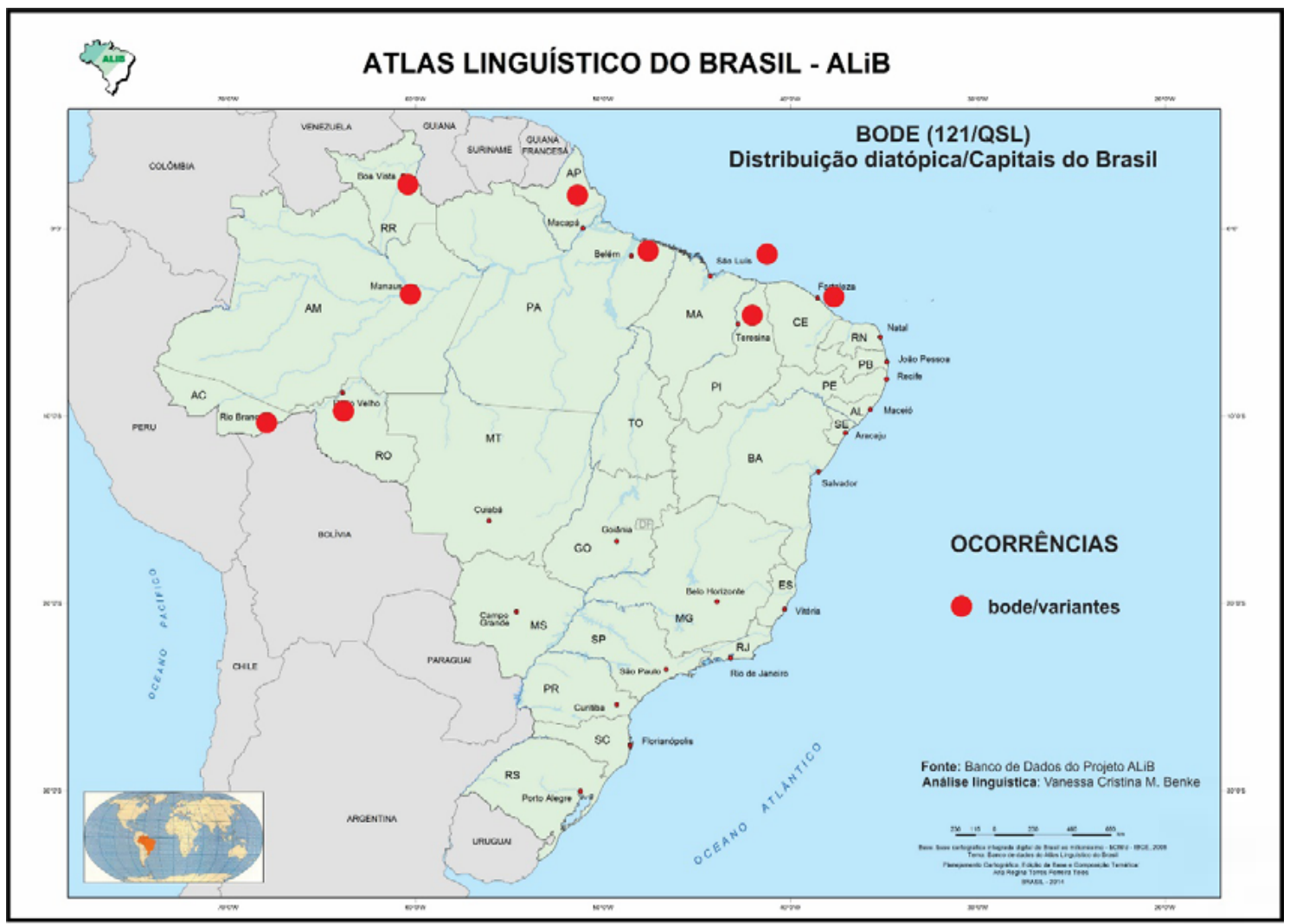

Fonte: Banco de Dados do ALiB. Elaborado pela autora

Percebe-se, pelos dados expostos na Figura 1, a concentração de bode/variantes nas capitais do Nordeste e, sobretudo, do Norte, evidenciando, assim, a presença de uma isoglossa ${ }^{9}$ dessa designação.

Chico/variantes, a terceira resposta mais produtiva no conjunto dos dados examinados, concentrou-se no Sudeste do Brasil, com maior produtividade na capital de São Paulo. No entanto, essa forma foi documentada também nas regiões Centro-Oeste e Sul, respectivamente, em Campo Grande e em Curitiba, duas capitais de Estados limítrofes com o Estado de São Paulo, o que pode indicar uma possível disseminação linguística. Essa designação foi mencionada também em Manaus (Norte) e em quatro capitais nordestinas: Aracaju, Maceió, Pernambuco e São Luís.

90 conceito de isoglossa é entendido com base nos pressupostos de Ferreira e Cardoso (1994, p. 12-13): "uma linha virtual que marca o limite, também virtual, de formas e expressões linguísticas". 
Do ponto de vista social, chico/variantes se destacou por sua ocorrência majoritária na fala dos idosos, alcançando $62,5 \%$ de registro entre os informantes dessa faixa etária, no âmbito das capitais pesquisadas, conforme demonstra o Gráfico 1:

Gráfico 1. Produtividade de chico/variantes nas capitais do Brasil segundo a variável idade

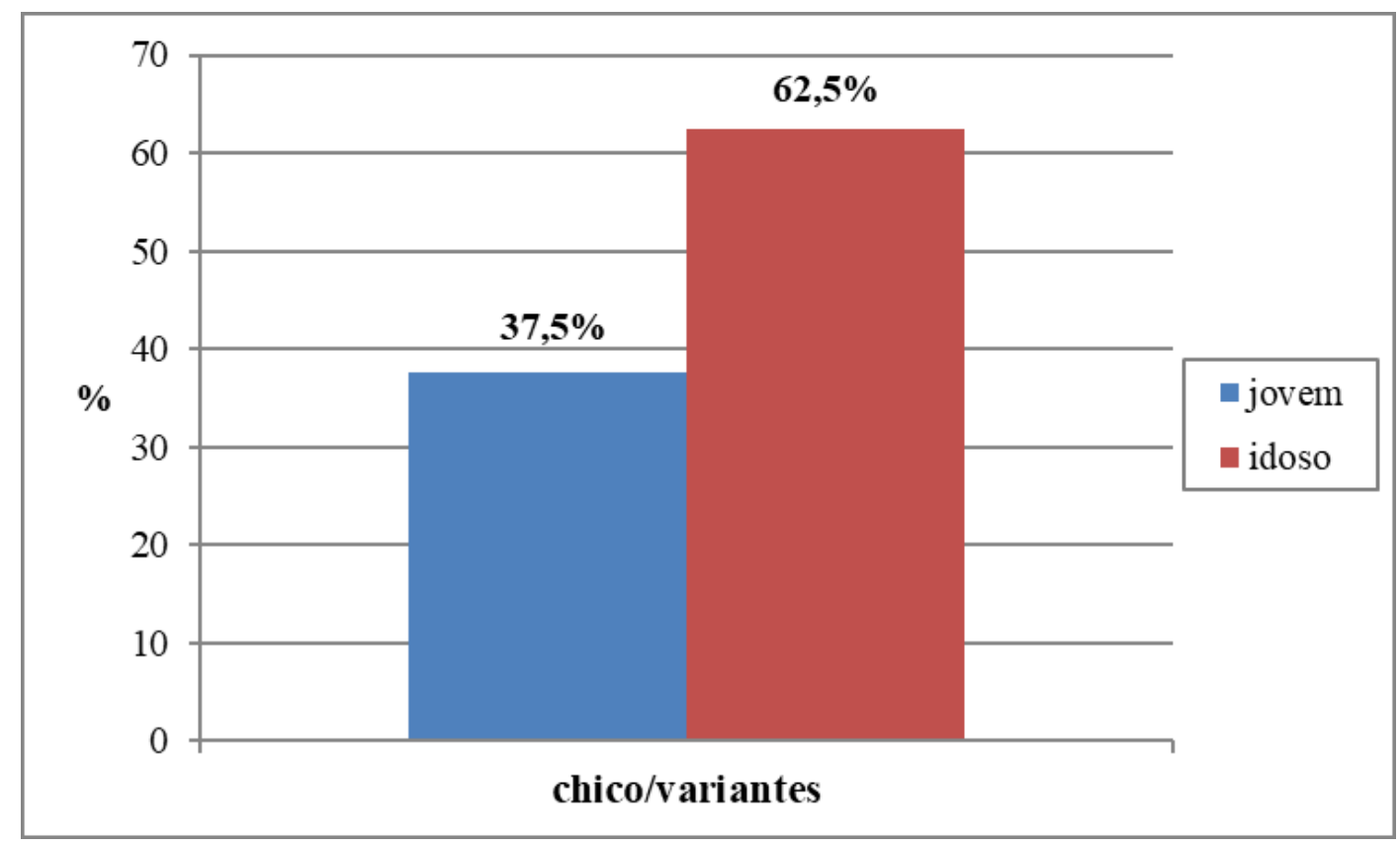

Fonte: Banco de Dados do ALiB. Elaborado pela autora

No rol das designações menos produtivas, estão sinal vermelho, bandeira/bandeira vermelha e paquete. Sinal vermelho foi fornecida apenas por quatro informantes, com ocorrências registradas em Boa Vista, Fortaleza, Belo Horizonte e Goiânia. Já bandeira/ bandeira vermelha foi registrada em Curitiba, Boa Vista e Fortaleza, capitais distantes entre si.

Paquete, por sua vez, registrou três ocorrências, duas em Vitória, uma em Florianópolis. Observa-se que essa unidade lexical, em particular, foi documentada apenas em capitais litorâneas, no Sul e Sudeste do Brasil, fato que a caracteriza como um léxico regional dessas capitais. Em relação à dimensão social, essa unidade lexical foi documentada apenas por informantes idosos, apontando para uma marca diageracional.

Já as formas linguísticas escrever com tinta vermelha, estar moranguinho e salário mínimo tiveram ocorrências únicas, todas documentadas em capitais nordestinas, respectivamente, em São Luís, Recife e Fortaleza. 


\section{Perspectiva léxico-semântica}

Como respaldo para a análise léxico-semântica das designações metafóricas, foram consultados dicionários brasileiros: Houaiss (2001) e Ferreira (2004); etimológico: Cunha (2007).

Além dessas obras lexicográficas, considerando a perspectiva de análise adotada para este estudo, foram consultados o Dicionário de Símbolos (CHEVALIER; GHEERBRANT, 2008) e o Dicionário do folclore brasileiro (CASCUDO, 1972). Cabe destacar, nesse contexto, que foi significativa a escuta dos áudios das entrevistas, não somente para fins de levantamentos de dados, como também para a sua análise semântica, contribuindo, assim, para a identificação de aspectos relacionados à interpretação dos dados aqui examinados, como o momento da resposta à pergunta em questão, considerando, neste caso, o tom de voz baixo decorrente do pudor e da hesitação por parte do informante ao proferir determinada designação tida como tabuística. Buscou-se também explicações fornecidas pelos informantes acerca do uso e da compreensão de uma dada nomeação.

No conjunto das designações metafóricas examinadas neste estudo, boi, bode, chico e bandeira registraram formas designativas tidas como derivação, isto é, designações de caráter fraseológico ${ }^{10}$ provenientes dessas unidades lexicais bases. 0 Quadro 1, a seguir, ilustra o exposto.

Quadro 1. Unidades lexicais "base" e designações derivadas para nomear o conceito "menstruação"

\begin{tabular}{|c|c|}
\hline Unidade lexical base & Derivação/Fraseologismos \\
\hline boi & boiada, de boi, estar com boi/ de boi \\
\hline bode & a mulher estar de bode, de bode, estar de bode \\
\hline chico & chiquinho, de chico, estar de chico \\
\hline bandeira & bandeira vermelha \\
\hline
\end{tabular}

Fonte: Banco de Dados do ALiB. Elaborado pela autora

Para o item lexical boi, Houaiss (2001) e Ferreira (2004) registram a acepção de "menstruação". O primeiro lexicógrafo atribui-Ihe a marca de uso informal, classificando-o como um regionalismo do Nordeste. Nessa perspectiva, não é demais lembrar que a figura do boi é valorizada nas tradições folclóricas nordestinas, o que pode justificar a referência a esse animal no processo de nomeação da "menstruação", majoritariamente nas capitais da referida região brasileira.

10 Usou-se o conceito de Fraseologia, com base na concepção "ampla" presente em Corpas Pastor (1996, p. 270), que adota diferentes estruturas fraseológicas. 
Esse processo metafórico com o uso do nome desse animal assemelha-se ao ocorrido com o nome do "bode", representando, portanto, a interferência de valores culturais e sociais de um grupo de falantes sobre a língua, mais precisamente, sobre o léxico. $\mathrm{Na}$ sequência, observa-se a figura do boi sob o olhar do folclore brasileiro:

\begin{abstract}
[...] pelas regiões da pecuária vive uma literatura oral louvando o boi, suas façanhas, agilidade, força, decisão. Especialmente no Nordeste, onde outrora não havia a divisão das terras com cerca de arame, modificando a fisionomia social dos agrupamentos, motivando uma psicologia diversa, os bois eram criados soltos, livres, nos campos sem fim [...]. Alguns touros e bois escapavam ao cerco anual e iam criando fama de ariscos e bravios. Eram os barbatões invencíveis, desaparecidos nas serras e várzeas, bebendo em olheiros escondidos e sesteando nas malhadas distantes. (CÂMARA CASCUDO, 1972, p. 166).
\end{abstract}

Considerando, portanto, o comportamento arredio do "boi", aventa-se a hipótese de que o uso do nome desse animal para designar a "menstruação" faz referência aos sintomas apresentados pela mulher durante esse período, como irritabilidade, alterações de humor, sentimentos violentos, além de dores que caracterizam, pois, a TPM (tensão prémenstrual). Com base nesse raciocínio, o uso da unidade lexical boi para designar "o sangue que a mulher perde todos os meses" indica um processo metafórico representado pelo sema"11 "comportamento".

Para a unidade lexical bode, Houaiss (2001) registra a acepção de "menstruação", classificando essa lexia como um regionalismo do Nordeste, de uso informal. Nesse particular, vale destacar que, conforme já assinalado, no subitem "perspectiva geossociolinguística", bode/variantes foi documentado pelo Projeto ALiB em capitais do Nordeste e do Norte, indicando, pois, uma disseminação linguística e descaracterizando, portanto, essa designação como um regionalismo do Nordeste. Essa propagação lexical pode ter uma explicação de cunho histórico, haja vista a grande leva de nordestinos que migraram para o Norte do Brasil, como mão de obra na extração da borracha que, consequentemente, contribuiu não só para o processo de formação cultural e social da região Norte, como também para a fixação de sua norma lexical.

A referência a esse animal para designar "o sangue que a mulher perde todos os meses", possivelmente, resulta da analogia estabelecida entre o cheiro exalado pelo animal e o cheiro característico do sangue eliminado pela mulher, associação que parece justificar o uso do item lexical bode para designar esse referente. Logo, o uso dessa unidade lexical metafórica reporta ao sema "odor".

11 Sema aqui é entendido a partir da concepção de Dubois (2006, p. 526-527): "unidade mínima da significação, não susceptível de realização independente e, portanto, sempre realizada no interior de uma configuração semântica ou semema". 
A respeito do odor emitido por esse caprino, Chevalier e Gheerbrant (2008, p. 134, grifo nosso) registram que "o bode, animal fedorento, torna-se símbolo de abominação, de rejeição (ou reprovação) ou, como diz Louis Claude de Saint-Martin, de putrefação e de iniquidade". Logo, a referência a esse animal para designar a "menstruação" tem conotação depreciativa e, consequentemente, tabuística, tendo em vista a associação estabelecida entre o mau cheiro do animal e o cheiro do sangue expelido pela mulher.

Do ponto de vista semântico, a designação em pauta tem, pois, caráter tabuístico, já que a maioria dos informantes resistiu em mencioná-la durante a entrevista, salvo com a insistência do inquiridor ${ }^{12}$. O trecho da entrevista, a seguir, da informante idosa de alta escolaridade, de Manaus, demonstra o caráter "chulo" imputado à unidade léxica bode:

INF. - Mas a minha vó chamava outro nome pá menstruação, tu tais o que (?) era uma outra, outra palavrinha que eu achava, eu queria esquecer, que eu achava tão vulgar.../INQ. - E esqueceu mesmo, hein!/INF. - E esqueci mesmo. Que achava tão vulgar, tá de... tá de bode. Meu Deus, eu acho isso tão vulgar, tão horrível. "Tá de bode hoje é?" De bode (Ponto 006/informante 8).

Outro trecho da entrevista com uma informante jovem com Ensino Fundamental, de Manaus, evidencia o caráter pejorativo de bode quando reportado à menstruação:

$I^{N} Q^{13}$. - Mas agora o nome bem popular?/ INF. - Menstruação.? INQ. - Não, popular!?/INF - Ah, é feio falar./ INQ. - Não, não é feio nada, não tem palavra feia./ INF - Regras./INQ. - O que mais?/INF - Tem gente que fala de bode também (Ponto 006/ Informante 2).

Observa-se, no excerto destacado, o receio da informante em proferir designações populares para "menstruação" e, ao mencionar "de bode", reforça em seu discurso que são outras pessoas que dizem essa forma, não assumindo, portanto, o uso desse sintagma como pertencente ao seu vocabulário. Isso atesta o conteúdo semântico negativo expresso em bode, conferindo o caráter tabuístico dessa unidade lexical.

Outra designação registrada foi chico e suas designações derivadas: chiquinho, de chico, estar de chico. O item lexical chico é definido como "menstruação" por Houaiss (2001) e por Ferreira (2004), o primeiro o classifica como um regionalismo do Brasil, de uso informal,

12 Notou-se, em todos os áudios das entrevistas, que bode/variantes não foi citada como primeira resposta pelos informantes, mas somente a partir da insistência do inquiridor ao questionar sobre outros nomes conhecidos para "menstruação", confirmando, pois, o caráter tabuístico dessa designação.

13 As abreviações INQ e INF indicam, respectivamente, a fala do inquiridor e a do informante (INF). 
enquanto o segundo, como um brasileirismo popular. Chico é, conforme Ferreira (2004), um hipocorístico de Francisco. No caso, o uso de chico representa uma forma metafórica com base em um nome próprio, para designar o conceito em pauta. O dicionário de Houaiss (2001) registra no verbete chica a acepção de "mênstruo", marcada como um regionalismo de Algarve, de uso informal. Logo, observa-se que chica - hipocorístico de Francisca utilizado em Portugal - no Brasil fixou-se como a forma masculina chico com o mesmo conteúdo semântico.

Nesse sentido, o item lexical chico representa uma personificação da "menstruação", pela atribuição de um antropônimo a um fenômeno fisiológico. Consoante Lakoff e Johnson (2002, p. 88-89), a personificação configura-se como

[...] uma categoria geral que cobre uma enorme gama de metáforas, cada uma selecionando aspectos diferentes de uma pessoa ou modos diferentes de considerá-la. O que todas têm em comum é o fato de serem extensões de metáforas ontológicas, permitindo-nos dar sentido a fenômenos do mundo em termos humanos, termos esses que podemos entender com base em nossas próprias motivações, objetivos, ações e características.

Nenhum sema relacionando ao sangue eliminado pelas mulheres foi identificado na definição da unidade lexical chico. Todavia, em consulta ao dicionário etimológico de Cunha (2007), verificou-se o seguinte registro para o verbete chico: "adj. 'pequeno' XIV. Do cast. chico, aparentado com o lat. cïrcum". "Chico", portanto, em sua origem castelhana, possui o sentido de "pequeno". Diante disso, e considerando o papel desempenhado pela personificação no processo metafórico, conforme Lakoff e Johnson (2002), levanta-se a hipótese de que o uso de chico, com base em seu sentido castelhano - "pequeno", quando empregado para nomear "o sangue que as mulheres perdem todos os meses", faz alusão ao espaço de tempo em que, normalmente, o sangue é eliminado pela mulher, que corresponde, em média, de 3 a 7 dias. Assim, em se tratando de um período relativamente curto, o uso de chico pode ter sido motivado por esse sema.

Semanticamente, chico/variantes possui caráter pejorativo, haja vista a manifestação de vergonha por parte da maioria dos informantes inquiridos ao proferir essa designação. Na sequência, o excerto seguinte, com uma informante idosa com Ensino Fundamental, de Belo Horizonte, ilustra o exposto:

INQ. - E antigamente chamava como?/INF. - Eles falava chico né? (risos)/Trem feio, né? Horroroso./INQ. - Por que será, né?/INF. - Que o nome de uma pessoa, Chico, que coita (coitado?), devia sê muito chato, né?/Coitado. Oh, meu Deus (risos) (Ponto 138/Informante 4). 
Outro trecho da entrevista com uma informante jovem, com baixa escolaridade, de São Paulo, também demonstra resistência ao proferir a unidade lexical chico em virtude do caráter chulo nela impresso, além de ser, segundo a informante, um termo utilizado por indivíduos de classe social popular:

INQ.- E qual o nome mais popular que a gente fala com as amigas?/INF.- Ai, é horrível, eu não falo. (risos)/INF - Ah... eu falo: "eu tô menstruada", mais os outros fala de chico né, aí é bem do povão (risos) (Ponto 179/Informante 2).

A designação chiquinho, ao contrário, representa uma forma eufêmica para designar "o sangue que a mulher perde todos os meses", haja vista tratar-se de um dos recursos de substituição dos vocábulos tabus elencados por Guérios (1979, p. 21): "os diminutivos muito especialmente são empregadíssimos. Foge-se a pronunciar o nome do diabo, mas diz-se afoitamente - diabito, diabinho, diabrete".

A forma sinal vermelho não apresenta a acepção de "menstruação" por nenhum dos lexicógrafos consultados. Nesse sentido, consultou-se o verbete sinal, assim definido por Ferreira (2004): "aquilo que serve de advertência, ou que possibilita conhecer, reconhecer ou prever alguma coisa". Já para a unidade léxica vermelho, o dicionário de símbolos, de Chevalier e Gheerbrant (2008, p. 944), registra, no verbete "vermelho-escuro", o significado de: "alerta, detém, incita à vigilância e, no limite, inquieta". Acrescentam, ademais, que essa tonalidade do vermelho possui uma significação fúnebre para a cultura pagã. Logo, o uso da forma fraseológica sinal vermelho exprime a ideia de alerta, para indicar que a mulher está em seu período de menstruação.

Nessa mesma linha semântica, temos a designação bandeira vermelha, que também não registra a acepção de menstruação nos dicionários consultados. Todavia, considerando que uma bandeira tem por função sinalizar algo e, associando essa finalidade à cor vermelha, tem-se, neste caso, uma simbolização de que a mulher está em seu período menstrual.

Nota-se, pois, o quão a menstruação é permeada de tabus, o que justifica a interdição vocabular, no que diz respeito às nomeações para designar esse período da fisiologia feminina. As designações bandeira vermelha e sinal vermelho representam, portanto, formas eufêmicas para nomear esse referente.

Já paquete, outra designação citada pelos informantes do Projeto ALiB para designar "o sangue que a mulher perde todos os meses", é registrada por Houaiss (2001) na acepção de "menstruação" e classificada como um regionalismo do Brasil, de uso informal. Ferreira (2004) também registra a mesma acepção para essa variante, classificando-a como um brasileirismo. Segundo Houaiss (2001), paquete é oriundo do 
inglês packet boat - "embarcação pequena e veloz para transporte de correspondência e transmissão de ordens". Vale ressaltar, nesse contexto, que "paquete", em seu sentido obsoleto (diacronismo) significa "navio mercante a vapor que prestava serviço de correio e transportava mercadoria e passageiros" (HOUAISS, 2001). Esse lexicógrafo esclarece, ainda, que a acepção de "menstruação" se deve ao fato de a embarcação passar em períodos regulares. Assim, paquete se configura como um recurso metafórico para designar a "menstruação", fazendo, pois, referência à regularidade do ciclo menstrual, representado pelo sema "periodicidade". O registro dessa variante apenas na fala de idosos confirma o seu caráter conservador, evidenciando, pois, uma marca diageracional.

No conjunto das metáforas apuradas, escrever com tinta vermelha, estar moranguinho e salário mínimo registraram ocorrências únicas. A primeira forma designativa não está dicionarizada nas obras lexicográficas consultadas. Todavia, o uso de escrever com tinta vermelha pode ser compreendido pela seguinte hipótese: o elemento verbal "escrever" faz referência ao processo de eliminação do sangue pelo corpo, enquanto a combinação "tinta vermelha" faz alusão ao sangue propriamente dito. Sendo assim, os semas expressos por essa expressão metafórica são: "eliminar" e "cor".

Já o uso de estar moranguinho nos reporta à fruta morango, associada, evidentemente, à sua cor vermelha. Portanto, o sema expresso por essa designação é "cor, representando, neste caso, uma analogia ao "sangue". Outro aspecto relevante dessa forma nominativa é o seu caráter eufêmico simbolizado pela forma diminutiva "moranguinho", já que, consoante Guérios (1979, p. 19), o diminutivo é um dos recursos utilizados para substituir os vocábulos tabus.

Salário mínimo, por sua vez, não registra a acepção de menstruação em nenhuma das obras lexicográficas consultadas. Todavia, o informante explica o seu uso da seguinte maneira: "só dá uma vez e só dura quatro a cinco dias" (Inf. 7). Essa assertiva confirma o caráter metafórico de salário mínimo para designar o referente em pauta, posto que o informante, ao utilizar essa forma designativa, associou o sentido literal expresso pela expressão salário mínimo à regularidade e ao período que ocorrem a "menstruação". Nesse processo metafórico estão simbolizados os semas "mensal" e "pouco".

Com base nos traços semânticos evidenciados no estudo das designações, tendo como suporte as acepções registradas nos dicionários consultados, bem como as explicações fornecidas pelos informantes nas entrevistas, as designações metafóricas aqui examinadas foram classificadas segundo as categorias semânticas por elas expressas, no que respeita ao seu uso para designar "o sangue que a mulher perde todos os meses". O Quadro 2, na sequência, detalha essa classificação. 
Quadro 2. Categorias semânticas atribuídas às nomeações metafóricas para "o sangue que a mulher perde todos os meses"

\begin{tabular}{|l|l|}
\hline \multicolumn{1}{|c|}{ Categorias semânticas } & \multicolumn{1}{c|}{ Metáforas } \\
\hline comportamento & boi/variantes \\
\hline cor & $\begin{array}{l}\text { estar moranguinho } \\
\text { escrever com tinta vermelha }\end{array}$ \\
\hline eliminação & escrever com tinta vermelha \\
\hline odor & bode/variantes \\
\hline período & $\begin{array}{l}\text { chico/variantes } \\
\text { paquete } \\
\text { salário mínimo }\end{array}$ \\
\hline sinalização & $\begin{array}{l}\text { bandeira/bandeira vermelha } \\
\text { sinal vermelho }\end{array}$ \\
\hline
\end{tabular}

Fonte: Banco de Dados do ALiB. Elaborado pela autora

Observa-se, pelos dados no Quadro 2, a diversidade de associações semânticas atribuídas às nomeações para a "menstruação", realizadas, por seu turno, a partir de palavras já existentes no sistema linguístico. Isso mostra que o processo de nomeação dos elementos da realidade de um grupo linguístico não é aleatório, mas ocorre a partir da sua relação com a realidade física e sociocultural do falante.

\section{Considerações finais}

O registro de criações metafóricas como designativos para "o sangue que a mulher perde todos os meses", no tocante à valorização adotada pelo falante em conjunto com a sua realidade social, referendou a tese da estreita relação entre o léxico e o ambiente físico, defendida por Sapir (1969, p. 43): "há uma forte tendência a atribuir muitos elementos da cultura humana à influência do ambiente em que se acham situados os participantes dessa cultura [...]". Já no que se refere ao reflexo desses valores metafóricos sobre a linguagem, pode-se inferir que esses dados ratificam a tese do relativismo linguístico defendida pela Hipótese Sapir-Whorf, de que a língua reflete a cosmovisão de uma civilização ou, nas palavras de Biderman (2001, p. 109): "cada língua traduz o mundo e a realidade social segundo o seu próprio modelo, refletindo uma cosmovisão que the é própria, expressa nas suas categorias gramaticais e léxicas". Nesse sentido, acredita-se que este estudo identificou o papel da língua, em especial o do léxico, como veiculador dos aspectos culturais pertinentes a um grupo linguístico.

Assim, o emprego de itens lexicais dessa natureza deu mostras de estereótipos que a sociedade adota sobre o mundo objetivo que, por seu turno, refletem valores sociais e culturais concernentes a uma civilização. Nesse contexto, as diversas referências 
utilizadas nesse processo metafórico, por exemplo, o resgate de nomes de animais, entre outros, aponta para a tese de que as metáforas, enquanto designativas para o conceito aqui pesquisado, mostraram-se motivadas, tendo em vista as evidências de relação de semelhança entre o conceito nomeado e o termo linguístico adotado, seja pelo comportamento, seja pelo cheiro, pela forma, entre outros semas evidenciados.

Enfim, o universo linguístico investigado demonstrou a interferência de aspectos sociais na escolha lexical dos habitantes dos grandes centros urbanos.

\section{REFERÊNCIAS}

BÍBLIA ONLINE. Disponível em: http://www.bibliaonline.com.br/. Acesso em: 9 jan. 2012.

BIDERMAN, M. T. C. Teoria Linguística: teoria lexical e linguística computacional. 2. ed. São Paulo: Martins Fontes, 2001.

CASCUDO, C. Dicionário do folclore brasileiro. Rio de Janeiro: Ediouro, 1972.

CASSIRER, E. Linguagem e mito. São Paulo: Perspectiva, 1972.

CHEVALIER, J.; GHEERBRANT, A. Dicionário de símbolos (mitos, sonhos, costumes, gestos, formas, figuras, cores, números). Tradução Vera de Costa e Silva et al. 22. ed. Rio de Janeiro: José Olympio, 2008.

COMITÊ NACIONAL DO PROJETO ALiB. Atlas Linguístico do Brasil: Questionários 2001. Londrina: EDUEL, 2001.

CORPAS PASTOR, G. Manual de fraseologia española. Madrid: Gredos, 1996.

COSERIU, E. O homem e a sua linguagem. Tradução Carlos Alberto da Fonseca e Mário Ferreira. Rio de Janeiro: Presença; São Paulo: Universidade de São Paulo, 1982.

CUNHA, A. G. Dicionário Etimológico da Língua Portuguesa. 3. ed. Rio de Janeiro: Lexicon, 2007.

DIÉGUES JÚNIOR, M. Regiões culturais do Brasil. Rio de Janeiro: MEC, INEP. Centro Brasileiro de Pesquisas Educacionais, 1960. 
DUBOIS, J. et al. Dicionário de Linguística. São Paulo: Cultrix, 2006.

FERREIRA, A. B. de H. Novo Dicionário Eletrônico Aurélio da Língua Portuguesa. 3. ed. Curitiba: Positivo, 2004. Versão 5.0.

HOUAISS, A. Dicionário Eletrônico Houaiss da Língua Portuguesa. Rio de Janeiro: Objetiva, 2001.

LAKOFF, G.; JOHNSON, M. Metáforas da vida cotidiana. Tradução Mara Sophia Zanotto. Campinas: Mercado de Letras; São Paulo: Educ, 2002.

GUÉRIOS, R. F. M. Tabus Linguísticos. 2. ed. aum. São Paulo: Ed. Nacional; Curitiba: Ed. da Universidade Federal do Paraná, 1979.

GUÉRIOS, R. F. M. A linguagem: introdução ao estudo da fala. Tradução Joaquim Mattoso Câmara Júnior. Rio de Janeiro: Instituto Nacional do Livro, 1954.

SAPIR, E. Língua e ambiente. In: SAPIR, E. Linguística como ciência. Tradução Joaquim Mattoso Câmara Júnior. Rio de Janeiro: Livraria Acadêmica, 1969. p. 43-62.

ULLMANN, S. A Semântica. Uma introdução ao estudo do significado. 5. ed. Lisboa: Fundação Calouste Gulbenkian, 1964. 